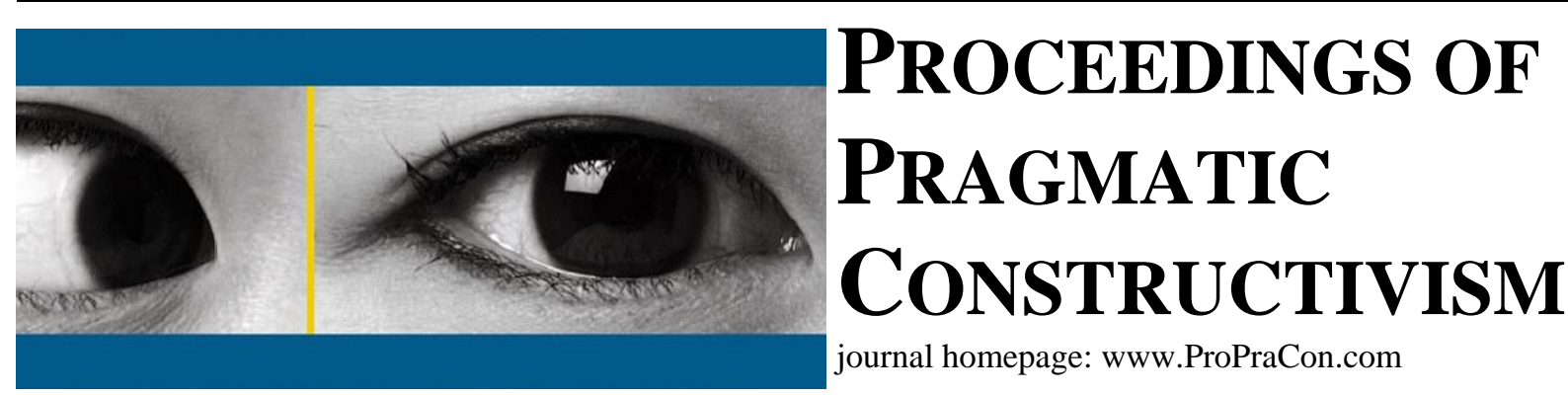

\title{
The Balanced Scorecard: the illusion of maximization without constraints
}

\author{
Morten Jakobsen \\ Associate Professor of Management Accounting and Control \\ Aarhus University; School of Business and Social Sciences; Department of Economics and Business \\ Fuglesangs Allé 4, 8210 Aarhus V, Denmark; mja@asb.dk \\ Rainer Lueg \\ Associate Professor of Management Accounting and Control \\ Aarhus University; School of Business and Social Sciences; Department of Economics and Business \\ Fuglesangs Allé 4, 8210 Aarhus V, Denmark; rlueg@asb.dk
}

\begin{abstract}
The Balanced Scorecard (BSC) claims to maximize organizational performance through the management of different perspectives (e.g., financial, customers, internal processes, learning \& growth). Most of the chosen measures are usually non-financial, as they are supposedly leading indicators of financial success. The developers of the BSC Kaplan and Norton see these perspectives as related, but not as linked to each other by accounting logic. Moreover, Kaplan and Norton recommend cascading the BSC across the organization by breaking up the BSC into sub-targets for each organizational unit.

Inevitably, this can lead to situations where actors in an organization focus on a subset of non-financial indicators. In their attempt to maximize these indicators, unit-egoism may lead to sub-optimal overall performance of the organization. This is because the link from non-financial indicators at lower levels of the organization to the overall financial goals have been disjoined. This problem, however, has been largely ignored in the BSC-literature. Therefore, this paper addresses the rationality and limits inherent in the usage of multiple performance measures. For this, we conduct an analytical study based on a literature review.
\end{abstract}

Keywords: Balanced Scorecard; non-financial measures; key performance indicators; sub-optimization; Value-based Management; accounting logic; decentralization. 


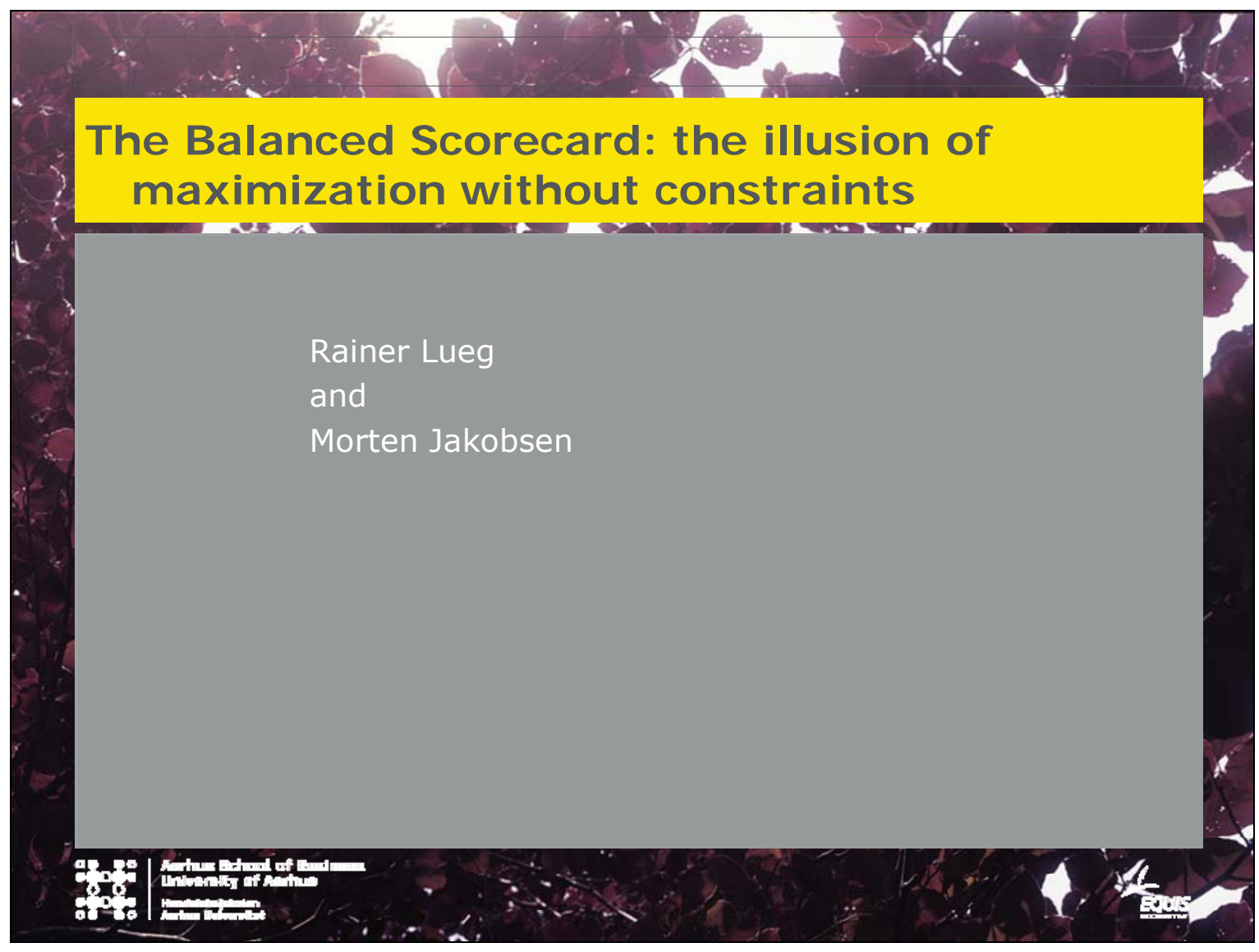

\section{Agenda}

- Background

- Objective and tentative research questions

- Method 


\section{Background Balanced Scorecard and Strategy maps}

- "What you measure is what you get!" is the driving ideology of the Balanced Scorecard

- The claim raised is that via measuring relevant aspects within Innovation and learning, Internal business and Customer perspective you will excel in the financial perspective.

- Though the perspectives seem interrelated on all levels, the rhetoric and the selected case strategy maps in the recent development of the Balanced Scorecard indicate that the basic perspectives determine the financial perspective.

\section{Background What gets the organisational attention}

- Within each perspective we find performance measures most of these are non-financial

- What characterises these performance measures is that people are expected to act in order to minimize or maximize the actual performance measure.

- Not to optimize as we know from economic rationality

- If this claim holds, and we actually gets what we measure, then the inherent optimization logic within accounting is lost when companies implement the Balanced Scorecard. 


\section{Objective and tentative research questions}

- Objective:

- The paper intends to reveal the rationality inherent in the usage of multiple performance measures

- Tentative research questions:

- Is there a difference in the rationality between onedimensional performance indicators and profit as a multidimensional performance measure?

- How do people act on one-dimensional performance indicators?

\section{Method}

- Analytical study based on literature review 


\section{References}

Albertsen, O. A., \& Lueg, R. 2014. The Balanced Scorecard's missing link to compensation: a literature review and an agenda for future research. Journal of Accounting and Organizational Change: forthcoming.

Bourguignon, A., Malleret, V., \& Nørreklit, H. 2004. The American Balanced Scorecard versus the French tableau de bord: the ideological dimension. Management Accounting Research, 15(2): 107-134.

Burkert, M., \& Lueg, R. 2013. Differences in the sophistication of Value-based Management - The role of top executives. Management Accounting Research, 24(1): 3-22.

Cinquini, L., Falconer, M., Nørreklit, H., \& Tenucci, A. 2012. Methodologies for managing performance measurement. In F. Mitchell, H. Nørreklit, \& M. Jakobsen (Eds.), The Routledge Companion to Cost Management: 342-359. New York, NY: Routledge.

Decoene, V., \& Bruggeman, W. 2006. Strategic alignment and middle-level managers' motivation in a Balanced Scorecard setting. International Journal of Operations \& Production Management, 26(4): 429-448.

Dilla, W. N., \& Steinbart, P. J. 2005. Relative weighting of common and unique Balanced Scorecard measures by knowledgeable decision makers. Behavioral Research in Accounting, 17(1): 43-53.

Ittner, C. D., Larcker, D. F., \& Meyer, M. W. 2003. Subjectivity and the weighting of performance measures: evidence from a Balanced Scorecard. The Accounting Review, 78(3): 725-758.

Jakobsen, M. 2013. Landbrugets stordrift uden driftsøkonomisk logik. Det Kgl. Danske Landhusholdningsselskab. Tidsskrift for Landøkonomi, 199(3\&4): 81-94.

Jakobsen, M., Johanson, I.-L., \& Nørreklit, H. (Eds.). 2011. An Actor's Approach to Management: Conceptual Framework and Company Practices. Copenhagen: DJØF.

Jakobsen, M., Mitchell, F., \& Nørreklit, H. 2010. Internal performance measurement systems: problems and solutions. Journal of Asian-Pacific Business, 11(4): 258-277.

Jakobsen, M., Mitchell, F., \& Nørreklit, H. 2011. Constructing performance measurement packages. In M. G. AbdelKader (Ed.), Review of Management Accounting Research: 194-213. Basingstoke: Palgrave Macmillan.

Jensen, M. C. 2010. Value maximization, stakeholder theory, and the corporate objective function. Journal of Applied Corporate Finance, 22(1): 32-42.

Kaplan, R. S., \& Norton, D. P. 2004. Strategy Maps: Converting Intangible Assets Into Tangible Outcomes. Boston, MA: Harvard Business Press.

Kaplan, R. S., \& Norton, D. P. 2006. Alignment: Using the Balanced Scorecard to Create Corporate Synergies. Boston, MA: Harvard Business School Press.

Lueg, R. 2008. Value-based Management: Empirical Evidence on its Determinants and Performance Effects. Vallendar: WHU Otto Beisheim School of Management.

Lueg, R. 2009. Führt der Einsatz externer Berater zur Überimplementierung innovativer Steuerungsinstrumente? Zeitschrift der Unternehmensberatung, 4(6): 249-253.

Lueg, R. 2010. Shareholder Value und Value Based Management - Wie steuern die HDAX-Konzerne? Zeitschrift für Controlling, 22(6): 337-344.

Lueg, R. 2010. Value-based Management - Antecedents and performance effects. In K. Pantz (Ed.), Summa Cum Laude 2008: Wirtschaftswissenschaften: 284-285. Darmstadt: Roter Fleck Verlag

Lueg, R., \& Carvalho e Silva, A. L. 2013. When one size does not fit all: a literature review on the modifications of the Balanced Scorecard. Problems and Perspectives in Management, 11(3): 86-94.

Lueg, R., Clemmensen, S. N., \& Pedersen, M. M. 2013. The role of corporate sustainability in a low-cost business model - A case study in the Scandinavian fashion industry. Business Strategy and the Environment: forthcoming.

Lueg, R., \& Jakobsen, M. 2014. Balanced scorecard and controllability at the level of middle managers - The case of unintended breaches. Journal of Accounting and Organizational Change: forthcoming.

Lueg, R., \& Lueg, K. 2013. The Balanced Scorecard and different Business Models in the textile industry - A case study. International Journal of Strategic Management, 13(2): 61-66.

Lueg, R., Nedergaard, L., \& Svendgaard, S. 2013. The use of intellectual capital as a competitive tool: a Danish case study. International Journal of Management, 30(2): 217-231.

Lueg, R., \& Nørreklit, H. 2012. Performance measurement systems - Beyond generic strategic actions. In F. Mitchell, H. Nørreklit, \& M. Jakobsen (Eds.), The Routledge Companion to Cost Management: 342-359. New York, NY: Routledge.

Messner, M. 2009. The limits of accountability. Accounting, Organizations and Society, 34(8): 918-938.

Nielsen, S., Jakobsen, M., \& Melander, P. 2009. The knowledge, attitude, priority of usage and benefits associated with management accounting practices: a survey of Danish companies. International Journal of Accounting, Auditing and Performance Evaluation, 5(3): 252-284. 
Nørreklit, H. 2000. The balance on the Balanced Scorecard: a critical analysis of some of its assumptions. Management Accounting Research, 11(1): 65-88.

Nørreklit, H. 2003. The Balanced Scorecard: what is the score? A rhetorical analysis of the Balanced Scorecard. Accounting, Organizations and Society, 28(6): 591-619.

Nørreklit, H., Jakobsen, M., \& Mitchell, F. 2008. Pitfalls in using the balanced scorecard. Journal of Corporate Accounting \& Finance, 19(6): 65-68.

Nørreklit, H., Nørreklit, L., Mitchell, F., \& Bjørnenak, T. 2012. The rise of the Balanced Scorecard - Relevance regained? Journal of Accounting and Organizational Change, 8(4): 490-510.

Young, S. D., \& O’Byrne, S. F. 2001. EVA and Value Based Management: A Practical Guide to Implementation. New York, NY: McGraw-Hill. 